\title{
POETYCKIE KARTKI Z ŁAGRU - CODZIENNOŚĆ I TĘSKNOTY (O POEZJI ŁARYSY MAROZAWEJ)
}

\author{
ПОЭТИЧЕСКИЕ ЗАПИСКИ ИЗ ЛАГЕРЯ \\ - ПОВСЕДНЕВНОСТЬ И ТОСКА \\ (О ПОЭЗИИ ЛАРИСЫ МАРОЗАВОЙ)
}

\author{
POETIC NOTES FROM THE CAMP \\ - EVERYDAY LIFE AND LONGINGS \\ (ABOUT LARISA MAROZAWA'S POETRY)
}

\author{
Katarzyna Cupała \\ Uniwersytet Wrocławski, Wrocław - Polska
}

\begin{abstract}
This article deals with poems of a Belarusian poet, Larysa Marozawa. Marozawa was one of the victims of Stalin's regime. The author puts forward the thesis that in Belarus today the same methods are used to eliminate political opposition as sixty years ago. The paper presents examples of modern political prisoners in Belarus. Next, the author analyzes several surviving works of Larysa Marozawa. The author is trying to prove that the atmosphere described in these poems may correspond with what is happening today in the labor camps in Belarus.

Słowa kluczowe: łagier, poezja białoruska, stalinizm, więzień polityczny

Ключевые слова: трудовой лагерь, белорусская поэзия, сталинизм, политзаключенный

Keywords: labor camp, Belarusian poetry, Stalinism, political prisoner
\end{abstract}

Białoruś jest teoretycznie niepodległym państwem położonym na wschód od Polski. Po obaleniu Muru Berlińskiego ów kraj, będący wcześniej republiką radziecką, stał się suwerenny, podobnie jak Polska, Litwa, Czechy i inne państwa, będące do tej pory pod rosyjskim obcasem. Jednakże Białorusini nie otrzymali wolności słowa, a władze białoruskie mają po dziś dzień charakter autorytarny. Sądy nie są niezawisłe, a przeciwników politycznych karze się tam, jak przestępców. Pamiętając te wydarzenia $\mathrm{z}$ naszego sąsiedniego kraju, które w niewielkiej i prawdopodobnie okrojonej ilości przedostawały się do polskich mediów (a zaraz potem przestawano o nich mówić), pragnę wysnuć dość odważną tezę, że na Białorusi od początku lat 40. XX wieku niewiele się zmieniło. Do dziś są tam łamane prawa człowieka, nie ma wolnych wyborów, a ludzie boją się otwarcie wygłaszać swoje poglądy. Dlatego też uważam, 
że wiersze Łarysy Marozawej, białoruskiej poetki, która zmarła w stalinowskim łagrze, można uznać za aktualne i oddające charakter czasów współczesnych na Białorusi.

Łarysa Marozawa była przez krótki czas żoną lejtnanta NKWD. Co może się zdać przedziwnym zbiegiem okoliczności, właśnie $\mathrm{w}$ dniu swojego ślubu została przez NKWD zatrzymana i przesłuchana. Wkrótce potem stalinowskie władze skazały ją na dziesięć lat łagru, za powód podając jej rzekomy udział $\mathrm{w}$ organizacji nacjonalistycznej. $\mathrm{W}$ międzyczasie mąż poetki został przez te same władze rozstrzelany. W obozie pracy Marozawa zaczęła pisać wiersze, kiedy zaś dowiedziała się o śmierci ukochanego, wyszła z baraku na mróz i na mrozie zmarła, najprawdopodobniej, samobójczą śmiercią w roku 19481 .

Niewiele wiadomo o tym, co się z nią działo przed skazaniem na prace w łagrze, nie jest znana data jej urodzin. Należy nadmienić, że poetka pisała zarówno w języku białoruskim, jak i rosyjskim. Przyjęła dwa pseudonimy artystyczne: utwory po białorusku sygnowała przydomkiem Lesia Białoruska (Леся Беларуска), natomiast pod napisanymi po rosyjsku podpisywała się Erinija (Эриния). Utwory Marozawej przetrwały częściowo dzięki ukraińskiemu poecie Wasylowi Małaguszowi, który zainteresował się jej losami. Pisarka Alena Kobiec-Filimonowa spisała wspomnienia Małagusza w książce Karelskija Kurapaty 1937-1938. Reha Gułaga. Tam też ukazały się wiersze Łarysy Marozawej. Pod koniec lat 90. niektóre jej utwory zostały wydane także w czasopiśmie „Polymia”. Obecnie białoruski historyk Anatol Bałachanowicz pisze książkę o losach poetki. Dzięki tym osobom Marozawa nie zostanie przez przyszłe pokolenia zapomniana ${ }^{2}$.

Dwa lata temu białoruski działacz społeczny Aleksandr Bialacki został skazany na cztery i pół roku kolonii o zaostrzonym rygorze, a państwo skonfiskowało jego mienie ${ }^{3}$. W mediach wybuchła wrzawa, przez prawie tydzień był to główny temat w wiadomościach. Nasuwa się pytanie, czy wydarzenia opisane $\mathrm{w}$ wierszach Marozawej tak bardzo różnią od współczesnej sytuacji na Białorusi? Teraz o Bialackim przestano mówić. Pewne jest natomiast, że został więźniem politycznym i że czeka go jeszcze dwa i pół roku przymusowego pobytu w kolonii.

Wśród politycznych więźniów na Białorusi nie tak dawno temu znaleźli się również Michaił Marynicz, polityk skazany w 2004 roku za działalność opozycyjną przez białoruskie KGB, uczestnik antyrządowej de-

\footnotetext{
${ }^{1}$ Писательница Елена Кобеи-Филимонова считает необходимым увековечить память талантливой поэтессы Леси Белоруски / / БелаПАН / Культура, 29.10.2007.

2 Ibidem.

${ }^{3}$ A. Tamkowicz, Aleś Bielacki, [w:] „Nowy Czas” 2009, [w:] źródło elektroniczne: http://pl.wikipedia. org/wiki/Alaksandr_Bialacki (01.10.2013).
} 
monstracji Zmicier Drozd został osadzony, podobnie jak Aleksandr Bialacki, w kolonii karnej o zaostrzonym rygorze. $W$ wywiadzie dla niezależnej telewizji Biełsat powiedział, że więźniów kolonii próbowano na różne sposoby zastraszyć, aby podpisali prośbę o ułaskawienie skierowaną do obecnego prezydenta Białorusi, Aleksandra Łukaszenkit.

Wiersze Marozawej, traktujące o bezsennych nocach w nieogrzewanych barakach, tłumieniu emocji i strachu w mroźnym i niewzruszonym otoczeniu łagru, do dziś mogą poruszyć odbiorcę. W utworze Yamy? zima jest odwzorowaniem dotkliwej samotności w obozie pracy. Wśród lodowatych podmuchów wiatru słychać lamenty głodnych i wyziębionych zesłańców. $W$ tej sytuacji każdy $\mathrm{z}$ nich jest bezradnym i przerażonym dzieckiem:

$$
\begin{aligned}
& \text { Нібы плачуць галодныя дзеці, } \\
& \text { нібы сіраты плачуць, не спяць } 5 \text {. }
\end{aligned}
$$

Mroźne krajobrazy w wierszu są sprzężone z emocjami zrozpaczonej kobiety. Ona tak widzi okolicę wokół siebie, ponieważ taka sama zima panuje $w$ jej uczuciach:

Над баракам - уснежаны вецер будзіць

горкую памяць паусстаць 6 .

Motyw głodu pojawia się też w innym wierszu Marozawej pod tytułem Maлimba да Калымы. Nawet księżyc świecący na niebie kojarzy się głodnemu człowiekowi ze skórką od chleba:

$$
\begin{aligned}
& \text { Месяц завіс залаты } \\
& \text { акрайчыкам хлеба уггары7 . }
\end{aligned}
$$

Upiorną atmosferę wokół potęguje gęsta mgła:

$$
\begin{aligned}
& \text { Белая даль навакол, } \\
& \text { ты нас імглой агарні: } \\
& \text { у̀ небе - крамлёу̃скі арол} 8 .
\end{aligned}
$$

Zesłaniec wie, kto odpowiada za jego krzywdy - władze rosyjskie:

$$
\begin{aligned}
& \text { Зрадніцца уे час які змаглі } \\
& \text { ікона і сякера - у Крамлі?! }
\end{aligned}
$$

4 A. Poczobut, Nie zamierzałem prosić Łukaszenkę o taskę, [w:] źródło elektroniczne: http://m.wyborcza.pl/wyborcza/1,105226,10119959,Nie_zamierzalem_prosic_Lukaszenke_o_ laske.html (01.10.2013).

${ }^{5}$ Ł. Marozawa, Чamy?, [w:] źródło elektroniczne: http://fsep.iatp.by/material/paezia / paezia.htm (01.10.2013).

${ }^{6}$ Ibidem.

7 Ł. Marozawa, Maлimba да Kалымы, [w:] źródło elektroniczne: http://fsep.iatp.by/ material/paezia/paezia.htm (01.10.2013).

8 Ibidem. 


\section{Пакуль сякера у̀сюды скача, \\ Заступніца паціху плача9.}

W poezji Łarysy Marozawej przewija się często wątek wyobcowania z dala od domu, beznadzieja, świadomość, że prawdopodobnie została przez wszystkich zapomniana. Nie widziała szans na wyjście z obozu, ale do momentu, kiedy dotarła do niej wieść o śmierci męża, usiłowała walczyć o przetrwanie. W utworze Бяссонніца opisana jest koszmarna noc w łagrze, kiedy człowiekowi zaczynają chodzić po głowie janczarniejsze myśli. Choć na zewnątrz panuje dotkliwy mróz, w ludzkich duszach co noc szaleje pożar:

На зямным абледзянелым шары

Маразы... Баракі... Людзі спяць...

I гараць у душах зноу пажары... ${ }^{10}$.

Nasila się pragnienie zemsty na oprawcach, za tak niesprawiedliwy osąd i karę za niewinność:

$$
\text { [...] помсты. I нічым іх не суняць!"11. }
$$

Człowiek pamięta swoją młodość jak przez mgłę, jak za kurtyną, której już nie można odsłonić - został pozbawiony marzeń i złudzeń na temat własnego życia:

$$
\begin{aligned}
& \text { Наперадзе - полюс усіх халадоў, } \\
& \text { Ахоцкае мора - пазадзе. } \\
& \text { Між імі - адно мая маладосць } 3 \\
& \text { замерзлай слязой у паглядзе }{ }^{12} \text {. }
\end{aligned}
$$

Warto nadmienić, że wiersz Бяссонніци Łarysa Marozawa napisała w dwóch częściach - pierwsza z nich powstała w obozie Elgen, druga $\mathrm{w}$ szpitalu więziennym. Jest to wyszczególnione pod strofami tego utworu ${ }^{13}$.

W wierszu Роздум jest przedstawiona dominacja rozumu nad sercem. Młoda dziewczyna zostaje zmuszona do porzucenia nadziei i marzeń o lepszym jutrze. Jej uśmiech przyprószył śnieg i teraz musi twardo stąpać po ziemi i myśleć realistycznie:

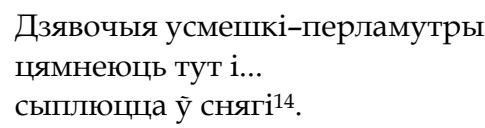

${ }^{9}$ Ibidem.

10 Ł. Marozawa, Бяссонніциа, [w:] źródło elektroniczne: http://fsep.iatp.by/material/paezia / paezia.htm (01.10.2013).

${ }^{11}$ Ibidem.

12 Ibidem.

${ }^{13}$ Ibidem.

${ }^{14}$ Ł. Marozawa, Роздyм, [w:] źródło elektroniczne: http://fsep.iatp.by/material/paezia/ paezia.htm (01.10.2013). 
Tego, co człowiek przeżywa w łagrze, nie sposób wyczytać z książek - żeby to zrozumieć, trzeba, niestety, doświadczyć zesłania na własnej skórze:

$$
\begin{aligned}
& \text { А прауда тая, - што на катарзе спасцігла, } \\
& \text { вось } 3 \text { гэтых, снегавых і вечных, кніг }{ }^{15} \text {. }
\end{aligned}
$$

Dusza upodabnia się tu do tajgi - jest niewzruszona i lodowata, ale mądrzejsza niż wszelkie złudzenia:

Адно: душа стае з гадамі...

мудрай, падобнай да калымскае тайгі16.

Wiersz Ціха спяюць пра нас odbiega charakterem od wymienionych powyżej. Ma atmosferę pieśni bohaterskiej, jest jednak jest bardzo ironiczny. Czytając go, można odczuć złość niesłusznie osądzonej osoby. Zaczyna się podniośle i można odnieść wrażenie, że w podniosłym tonie będzie utrzymany do ostatniego wersu. Jednak koniec jest przewrotny. Zesłaniec zachęca do śpiewania pieśni na cześć bohaterskich zesłańców:

$$
\begin{aligned}
& \text { Скажам - спявайце! } \\
& \text { - цудоўнай парой напрадвесні. } \\
& \text { Свайго дачакаемся часу і мы... }{ }^{17} .
\end{aligned}
$$

Ironia pojawia się, kiedy wspomina, że w więźniowie pełni są nadziei i marzeń:

Калі будзе свята, свята лагернай песні, думак і мар, і надзей Калымы...18.

Pod koniec wiersza pojawia się wzmianka o trupach, które czernieją pod oblodzoną ziemią:

$$
\begin{aligned}
& \text { [...] Толькі з-пад снегу } \\
& \text { чарнеюцца трупы, нібы шматкроп'е } \\
& \text { Песні Вякоу.... }{ }^{19} \text {. }
\end{aligned}
$$

W podobnym tonie jest utrzymany utwór Даччыное. W tym wierszu w pierwszej osobie wypowiada się sama Białoruś (występuje więc tutaj personifikacja całego państwa). Twierdzi, że od zawsze była wrogiem przemocy, gwałtownych protestów i społecznego zakłamania:

${ }^{15}$ Ibidem.

16 Ibidem.

17 Ł. Marozawa, Ціха спяюць пра нас, [w:] źródło elektroniczne: http://fsep.iatp.by/material /paezia/paezia.htm (01.10.2013).

18 Ibidem.

19 Ibidem. 


\section{Роднай Беларусі \\ Я - вораг гвалтоўных акцый, хлусні і пагардлівых жэстаў 20.}

Jej dominującą cechą charakteru jest duma, a najważniejszym mottem życiowym „Nie poddawaj się!":

Быў адказ мой зауужды: - „Не здаюся"21.

Białoruś przedstawiona $\mathrm{w}$ wierszu stanowi kawałek cywilizacji, uciśniony kraj, w którym mimo przeciwności losu ludzie nie zapominają o swojej tożsamości narodowej:

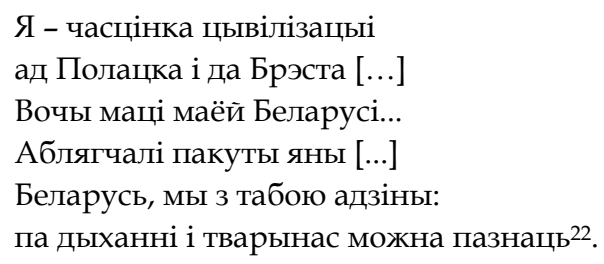

W utworze Я сёння іншая pojawia się zwątpienie w sens dalszej walki. Więźniarka twierdzi, że opadła z sił, jej młodość minęła bezpowrotnie:

Я сення іншая, бясспрэчна,

мяне 3 рудой век пераплавіӯ...23.

Wspomina rodzinne miasto, Mołodeczno, i porównuje siłę i niewzruszenie tego miasta do własnych możliwości, twierdzi, że więcej sił już nie ma:

$$
\begin{aligned}
& \text { Ды родны горад Маладзечна мацней, } \\
& \text { чым я, ніхто не славіӯ! } 24 .
\end{aligned}
$$

Zastanawia się, jak to jest, że mimo tych wszystkich okropnych wydarzeń Białoruś dalej istnieje, a pamięć o niej jest przekazywana z pokolenia na pokolenie. Jeden człowiek nie może bowiem unieść ciężaru codzienności w obozie pracy:

$$
\begin{aligned}
& {[\ldots . .] \text { каханай Беларусі! }} \\
& \text { Адкуль бярэцца толькі сіла? } \\
& \text { Сцярплю у̃се мукі і у̀се болі²5. }
\end{aligned}
$$

${ }^{20}$ Ł. Marozawa, Даччыное, [w:] źródło elektroniczne: http://fsep.iatp.by/material/paezia/ paezia.htm (01.10.2013).

${ }^{21}$ Ibidem.

22 Ibidem.

${ }^{23}$ Ł. Marozawa, Я сення іншая, [w:] źródło elektroniczne: http://fsep.iatp.by/material/ paezia/paezia.htm (01.10.2013).

${ }^{24}$ Ibidem.

${ }^{25}$ Ibidem. 
Równocześnie zesłana kobieta wspomina, że bardzo tęskni za swoim krajem i ta tęsknota powoduje $u$ niej odrętwienie:

Мая душа з любві нямее...

Край продкаӯ мілы, я клянуся:

так аніхто любіць не уммее, як я [... $]^{26}$.

W wierszu Eфрасінні Полацикай pojawia się porównanie cierpienia zesłańców do męki Chrystusa na krzyżu:

Сыходзяцца шляхі, нібы у̃ крыжы,

- твой золатам убраны, мой - „калючай”27.

Zesłaniec ma dwie siostrzane dusze - jedna przebywa w okolicy Kołymy, druga w Jerozolimie:

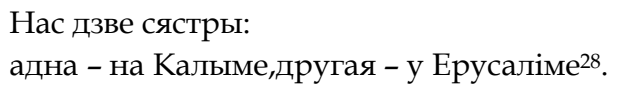

Jednak więźniom nie postawiono żadnego kościoła i nikt się do ich wizerunków nie modli w świątyniach. Mimo wszystko umierają na metaforycznym krzyżu, jakim jest zesłanie:

Ты мураваныя апекавала храмы...

Я ж душы тут, як храмы, берагу29.

Wiersz $Y$ rece traktuje o wszystkich ofiarach reżimu - od zapomnianych przez świat, przedwcześnie zmarłych poetów (lub tych, których utwory nigdy nie zostały przez nikogo przeczytane) po bezimiennych ludzi, wykończonych pracą $\mathrm{w}$ obozie. Ich szczątki spoczywają w lesie, pod drzewami i najprawdopodobniej nikt się o nich nigdy nie dowie:

Невядомая для свету паэтэса,

дрэу̃ паӯночных гладжу я кару казачнага лагернага лесу... ${ }^{30}$.

Tu znów pojawia się motyw bezpowrotnie utraconej młodości:

Ці тым самым нашумелым навабудам,

дзе мінала маладосць мая 31.

Więźniarka pragnie uwierzyć w nieśmiertelność i stara się bez strachu myśleć o przyszłości:

26 Ibidem.

${ }^{27}$ Ł. Marozawa, Ефррасінні Полац̧кай, [w:] źródło elektroniczne: http://fsep.iatp.by/ material/paezia/paezia.htm (01.10.2013).

${ }^{28}$ Ibidem.

${ }^{29}$ Ibidem.

${ }^{30}$ Ł. Marozawa, $У$ ıесе, [w:] źródło elektroniczne: http://fsep.iatp.by/material/paezia/ paezia.htm (01.10.2013).

31 Ibidem. 


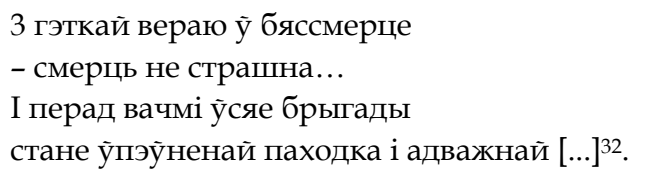

Wciąż towarzyszy jej motto już wspomniane w jednym z powyżej zanalizowanych utworów: „Nie poddawaj się!”:

...наша Леся адышла сама у̀ манады,

ворагам сказауушы: „Не здаюся!” 33.

Utwór Moũ cbem utrzymany jest w podobnym tonie, co pozostałe. Skazaniec żali się, że jego świat został okradziony z kolorów i teraz otacza go czerń:

Яго чарнілі. Рабавалі. Гналі на плаху.

На разброд. На Калыму 34.

Ciężko jest bowiem zachować jakiekolwiek kolory, kiedy żyje się w obozie pracy, z dala od domu. Niełatwo pogodzić swoje wyobrażenia o świecie z otaczającym człowieka kłamstwem, obłudą i okrucieństwem:

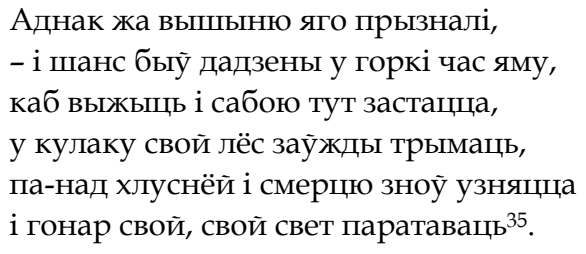

Poezja Łarysy Marozawej porusza do dziś aktualne na Białorusi tematy: lęk przed tym, co skazanego niesłusznie człowieka czeka w więzieniu, jak tam będzie traktowany, czy w czasie jego pobytu w zamknięciu nie zapomną o nim najbliższe osoby i czy świat zachodni pewnego dnia upomni się o niego. Można sobie wyobrazić, że podobne rozterki przeżywają dzisiejsi więźniowie polityczni na Białorusi. Ich kraj jest w dalszym ciągu wieloma koligacjami powiązany z Rosją i zarówno władze białoruskie, jak i rosyjskie czerpią korzyści z braku demokracji. Jak w każdym kraju autorytarnym, najbardziej cierpią ci, którzy pragną przemian ustrojowych i wolności. Świadectwa takich osób, jak Zmicier Drozd, świadczą o tym, że sposoby łamania więźniów politycznych na Białorusi obecnie nie odbiegają znacząco od metod, które były stosowane przez władze we wczesnych latach 40 . XX wieku.

32 Ibidem.

${ }^{33}$ Ibidem.

${ }^{34}$ Ł. Marozawa, Moũ cbem, [w:] źródło elektroniczne: http://fsep.iatp.by/material/paezia /paezia.htm (01.10.2013).

35 Ibidem. 


\section{Bibliografia}

1. А. Кобец-Філімонава, Карэльскія Курапаты 1937-1938. Рэха ГУЛАГа, Мінск 2007.

2. A. Poczobut, Nie zamierzałem prosić Łukaszenkę o łaskę, [w:] źródło elektroniczne: http://m.wyborcza.pl/wyborcza/1,105226,10119959,Nie_zamierzalem_ prosic_Lukaszenke_o_laske.html (01.10.2013).

3. Писательница Елена Кобец-Филимонова считает необходимым увековечить память талантливой поэтессы Леси Белоруски // БелаПАН / Культура, 29.10.2007.

4. A. Tamkowicz, Aleś Bielacki, „Nowy Czas”, 2009, [w:] źródło elektroniczne: http://pl.wikipedia.org/wiki/Alaksandr_Bialacki (01.10.2013). 